ORIGINAL ARTICLE

\title{
Preliminary analysis of reproductive, behavioral and physiological characteristics of military working dogs
}

Graziele Braido Arcuri ${ }^{1}$ (D), Messy Hannear de Andrade Pantoja² (D), Cristiane Gonçalves Titto ${ }^{2}$ (D), Daniele dos Santos Martins ${ }^{1 *}$ (D)

\author{
${ }^{1}$ Departamento de Medicina Veterinária, Faculdade de Zootecnia e Engenharia de Alimentos, Universidade de São Paulo, \\ Pirassununga, SP, Brasil \\ 2Departamento de Zootecnia, Faculdade de Zootecnia e Engenharia de Alimentos, Universidade de São Paulo, Pirassununga, \\ SP, Brasil
}

How to cite: Arcuri GB, Pantoja MHA, Titto CG, Martins DS. Preliminary analysis of reproductive, behavioral and physiological characteristics of military working dogs. Anim Reprod. 2022;19(2):e20210092. https://doi.org/10.1590/1984-3143-AR2021-0092

\begin{abstract}
The use of dogs in military work environments has always aroused great interest in the general population and determining the stress levels they go through is extremely important to maintain their welfare. The aim of this research was to evaluate if the work shifts in military working dogs leads to stress conditions and if this working influences on the reproductive performance and life quality. The study was conducted at the Military Police Kennel located at Campinas, Sao Paulo, Brazil. Eight male dogs of four different breeds (German Shepherd, Belgian Malinois Shepherd, Doberman, and Rottweiler) were evaluated during two different shifts: Working Shifts: animals working 12 hours a day with 2 hour-interval; and Control Shifts: animals that were on their day off (36 hours). Saliva samples were collected for cortisol analysis at the control and working shifts. The study was carried out over 60 days and analyzed behavior, physiology, and reproduction quality. Saliva samples, behavior observation of stereotyping, resting and moving activities and semen analysis were collected by digital stimulation (for combined second and third fractions). The salivary cortisol levels during the control and working shifts were between $0.361-0.438$ and $0.312-$ $0.592 \mu \mathrm{g} / \mathrm{dL}$, respectively; the highest values were found at the end of working shifts. The animals were resting during most of the observation period, but few showed stereotypic behaviors. The testicular consistency was firm and semen parameters were within the normal values in German Shepherd, Belgian Malinois Shepherd, and Doberman dogs. However, Rottweiler dogs had a higher rate of sperm abnormalities, higher salivary cortisol levels, and more stereotypic behaviors. Nevertheless this work highlights the importance of further research relating reproduction and cortisol levels in military dogs.
\end{abstract}

Keywords: behavior, semen quality, military dog, breed, welfare.

\section{Introduction}

Dogs have been active members of society since old times and they act to protect and provide company, including human work functions (Broom and Fraser, 2010). Specialized trained dogs work in forensic sciences to help on crime solutions, through their keen sense of smell, as they can identify explosive, drugs, chemical substances, or even human individual odor (Burghardt, 2003; Haverbeke et al., 2008). Actually, the demand for canines highly capable explosives detection due to the increases in emerging sophisticated threats needs (Lazarowski et al., 2020). Using dogs for working functions requires a different intensity of 
effort in comparison to dogs designed as pets, to expositions or laboratory activities (Möstl and Palme, 2002; Rooney et al., 2016).

Therefore, these animals may be more susceptible to stress, which leads to negative behavioral, hormonal (Hekman et al., 2014; Petersson et al., 2017), and reproductive changes (Kolster, 2018; Kumar et al., 2019). Impaired welfare results in abnormal behaviors, including running toward or away from the owners, hypervigilance (Mills et al., 2014), circling repeated turning, licking of objects for extended periods with no obvious purpose, or fixation to an item (Hall et al., 2015). Therefore, under stressful conditions, the behavior and cortisol levels of dogs should be evaluated because the plasma cortisol levels increase in response to stress (Starling et al., 2005; Chmelíková et al., 2020).

In addition to inducing behavioral and hormonal changes, stress can significantly decrease the quality of semen, such as decrease in sperm motility, increase in the number of dead sperm, increase in number of spermatic membrane alterations, high cytoplasmic drop retentions, and acrosomes alterations, indicating an impaired function of the epididymis (Baptista et al., 2009).

The knowledge of acceptable welfare patterns to reduce stress, which impairs the quality of life and fertility in dogs, can improve the management efficiency of working dogs. Besides a better performance of these military working animals, it is an important contribution to police, public safety, and crime preventive areas.

The study aimed to evaluate the possible effects of stress on the management of military working dogs by evaluating their behavior, salivary cortisol level, and semen parameters.

\section{Methods}

\section{Animals and facilities}

The animal study was reviewed and approved by the Ethics Committee of the Veterinary Medicine School at the University of São Paulo, Brazil (protocol number: 2633191120). Written informed consent was obtained from the owners for the participation of their animals in this study

The experiment was conducted at the $1^{\text {st }}$ Especial Action Police Crowd (in Portuguese BAEP), Campinas, SP, Brazil. Eight male dogs (weight: $40 \mathrm{~kg}$, age: 48 months, work experience: 36 months) of four different breeds two German Shepherd (weight: 28 and $31 \mathrm{~kg}$, age: 4 and 3 years old respectively), two Rottweiler (weight: 38 and 40kg, age: 2 and 3 years old respectively), two Doberman (weight: 40 and $43 \mathrm{~kg}$, age: 3 years old) and two Belgian Shepherd Malinois (weight: 25 and 27kg, age: 5 and 4 years old respectively) were used.

The animals were housed in individual kennels (dimensions $\mathrm{H} \times \mathrm{L} \times \mathrm{W}: 2.1 \times 4 \times 2 \mathrm{~m}$ ), with $3 \mathrm{~m}^{2}$ of roofing area and $5 \mathrm{~m}^{2}$ of a solarium. All houses had a water hole with potable water and a metal feeder, sewage pipe, wooden floor $\left(2.25 \mathrm{~m}^{2}\right)$, door with glass window and security locks, cemented floor with gradual inclination toward the drain and artificial lights according to the recommendations of the Decree 40400, October 241995 (São Paulo, 1995). The animals were fed commercial premium meals once a day, according to the National Research Council requirements, and had ad libitum access to the potable water. The dogs are vaccinated and dewormed according to the kennel calendar. In addition, clinical examination (complete physical examination) and laboratory analysis (blood and urine) were performed periodically.

All animals started basic training 6 to 8 months and extended to 12 months. All animals have the same training and after 12 months the animal starts its field work. From 12 months the animals continue in constant training to reinforce the knowledge acquired. Military dogs must be trained until the end of their military career, but always keeping the same objective. Each animal has a trainer, a policeman who takes care of the 
dog on working days. When the trainer has an off day, the animal remains in its dog house. On off days, all animals are cleaned and receive food and water. All dogs have a $12 \mathrm{~h}$ working routine. The dogs undergo military training from 7:00 a.m. to 10:00 a.m. The working routine starts at 6:00 a.m. until 10:00 a.m. and restarts at 1:00 p.m. until 6:00 p.m. when the dogs go back to their kennel. After one work day of 12 hours, the animals rest for 36 hours.

\section{Experimental design}

The experiment was divided into two different shifts: control shift (C) when animals day-off working and the working shift (W) when animals were working in military routine. The working military daily routine involves obey basis, military physical conditioning and sniffing (to drugs, people, firearms or other weapons). The military work includes street policing, where the dog goes to the police car and is engaged with narcotics occurrences, criminal and weapons finding.

There was an adaptation period (7 days) to the management procedures, subsequently the experiment was carried out during 60 days for evaluations of behavior, hormonal and reproductive analysis.

\section{Evaluation of animal behavior}

Animal behavior was performed individually inside their kennels, by visual and direct observations, with instantaneous recording by focal sampling, from 6:00 a.m. to 8:00 a.m., and from 4:00 p.m. to 6:00 p.m., five minutes duration to each dog in each period. The total time to each animal was 600 seconds. The behavioral variables observed were (Haverbeke et al., 2008): Stereotypic behaviors, rest and movement behaviors (Table 1).

Table 1. Behavioral description (adapted Haverbeke et al., 2008).

\begin{tabular}{ll}
$\begin{array}{ll}\text { STEREOTYPIC BEHAVIOR } \\
\text { Repetitive walking }\end{array}$ & $\begin{array}{l}\text { Repeat immediately a path just taken and continuing in the repetition; in circles, in } \\
\text { a figure in the form of eight or walking in line on the fence / wall }\end{array}$ \\
\hline Circling & Continuous walking in short circles, apparently chasing its tail or hind limbs \\
\hline $\begin{array}{l}\text { Manipulation of } \\
\text { environment }\end{array}$ & $\begin{array}{l}\text { Stereotypic interactions with elements from the environment; digging (= scratching } \\
\text { the floor with the forepaws to a way that is similar to when dogs are digging holes); } \\
\text { floor licking (= licking the floor with the tongue); rubbing legs against bars, gnawing } \\
\text { at bars or at other material of the environment }\end{array}$ \\
\begin{tabular}{ll} 
REST BEHAVIOR & Trunk of body on cage floor \\
Prone, head up & Hindquarters and front paws only in contact with cage floor \\
\hline Sit & $\begin{array}{l}\text { Hindquarters and front paws only in contact with cage floor. head in contact with } \\
\text { the grid of cage }\end{array}$ \\
\hline Sit, head in the grigh \\
\hline Stand & Bpright with at least three paws in contact with cage floor \\
\hline Oral behaviors & $\begin{array}{l}\text { Trunk of body on cage floor, chin or side of head in contact with cage side or floor, } \\
\text { paws or limbs }\end{array}$ \\
\hline Prone, head down & Upright with at least two paws in contact with floor \\
\hline Stand on two legs & Takes at least one step, shifting body position \\
\hline MOVEMENT BEHAVIOR & Nose moved along objects and/or clear sniffing movements are exhibited \\
\hline Walk & Urinating while raising one hind limb posteriors \\
\hline Sniff & Excreting the contents of the bowels \\
\hline Urinating & Drink water from the drinking fountain \\
\hline Defecating & Barking, roaring, growling, whining, yelping \\
\hline Drinking & Eating food from the feeder \\
\hline Oral behaviors & \\
\hline Eating &
\end{tabular} \\
\hline
\end{tabular}




\section{Cortisol levels}

During the WS, the saliva samples from each dog were collected four times a day for 3 days-T0: before training (7:00 a.m.), T1: after training (10:00 a.m.), T2: before training after a rest period (1:00 p.m.), and T3: at the end of the daily routine (7:00 p.m.). During the CS, the saliva samples from each dog were collected two times a day for 3 days-morning (7:00 a.m.) and afternoon (6:00 p.m.).

For determination to cortisol concentrations, saliva samples were collected by using the Salivette ${ }^{\circledR}$ tubes (SARSTEDT Ref 51.1534.500) that have a high absorbable swab. The oral cavity of the animals was previously cleaned with filtered water and then the animals were stimulated to chew the swab for three to five minutes.

The saliva samples were centrifuged at 2,000 rpm for $5 \mathrm{~min}$ and the supernatant was separated and stored at $-20^{\circ} \mathrm{C}$. Subsequently, the cortisol level was quantified using an electrochemiluminescence method. The mean intra- and inter-assay coefficients of variation were $7.1 \%$ and $11.5 \%$, respectively.

\section{Semen quality}

The Testicular consistency was measured by palpation, always by the same technician. Using a scale from one to five for classification, where: 1- friable consistency; 2- intermediate consistency; 3firm consistency (desirable); 4- turgid consistency and 5- hard consistency (Baptista et al., 2009).

The semen was collected in both experimental periods by digital manipulation (Kutzler, 2005) for combined second and third fractions and maintained at $37^{\circ} \mathrm{C}$. After collection, the proportion of motility spermatozoa present in the semen samples was immediately estimated subjectively using optical microscopy (100x) (CBRA, 2013) and referred as overall sperm motility. A semen sample was thereafter in buffered formol-saline solution could be used to detect nuclear, acrosome and tail abnormalities, as well as the location of cytoplasmic droplets, on 200 spermatozoa per sample

The spermatic concentration $\left(\mathrm{CONC} \times 10^{6} \mathrm{sptz} / \mathrm{mL}\right)$ was evaluated in a Neubauer chamber. The semen was diluted 1:20 a 50- $\mu \mathrm{L}$ aliquot of ejaculated and $950 \mu \mathrm{L}$ of distilled water or $10 \%$ buffered saline formalin. The sperm count was performed under phase contrast microscopy, with a magnification of 1000x (Ax et al., 2004).

The sperm morphology was performed by semen smear, using glass slides, fixed with saline formalin during $10 \mathrm{~min}$ at water bath $37^{\circ} \mathrm{C}$, dried at room temperature and stored. The slides were colored by the Karras modified method (Papa et al., 1988), and counted 200 cells, using phase contrast optical microscopy under magnification of $1.000 x$. The spermatozoa were evaluated and classified as minor sperm defects (MiD, \%, head defects, tail defects and implantation, and distal cytoplasmic droplets), major defects (MaD, \%, acrosome defects, head defects, proximal cytoplasmic droplets, teratological forms, abnormal midpiece, tail defects and double forms) and total defects (TD, \%) (Ax et al., 2004).

\section{Statistical analysis}

The salivary cortisol level data were analyzed by variance analysis (MIXED-SAS) using two approaches-1) to compare the WS and CS, fixed effects of breed, time (7 a.m. and 6 p.m.), the shifts, and its current interactions were used; 2 ) to evaluate only the WS, fixed effects of breed, time (7 a.m., 10 a.m., 1 p.m., and 6 p.m.), and its interactions were used. Animals were used as repeated measures. The average results were compared using the $\mathrm{F}$ test, $\mathrm{T}$ test, or TukeyKramer test as applicable.

Behavior data were analyzed using exploratory analysis, with the objective of characterizing data distribution and the source of relevant variations, by those results, adjusted model, and general linear theory models (GLIMMIX-SAS). To evaluate each behavioral variable, starting on the percentage of frequencies of different occurrences of variable categories related to the behavioral variables, the data were adjusted to "Arc-Sen percentage root" and then, variance 
analysis was performed. Statistics model considered as fixed effects breed, day period (morning or evening), shifts (working or control), and its interactions to multiple comparisons procedure (PDIFF). Animals were used as repeated measures. To present the results, the data were turned back to the original shifts. All tests were performed at 5\% probability. SAS 9.3 software (2012) was used for all analyses.

\section{Results}

\section{Animal behavior}

The behavior analysis evidenced resting phases during most of the time (Table 2).

Table 2. Mean values of the daily (morning and afternoon) behavior of military working dogs of different breeds expressed as seconds per activity.

\begin{tabular}{|c|c|c|c|c|c|}
\hline \multirow[b]{2}{*}{ Behavior } & \multicolumn{4}{|c|}{ Breeds } & \multirow[b]{2}{*}{ P value } \\
\hline & $\begin{array}{l}\text { German } \\
\text { Shepherd }\end{array}$ & $\begin{array}{c}\text { Belgian } \\
\text { Malinois }\end{array}$ & Doberman & Rottweiler & \\
\hline \multicolumn{6}{|l|}{ Stereotypic Behavior } \\
\hline Repetitive walking & $3.95 \mathrm{~b}$ & $2.45 \mathrm{~b}$ & $0 \mathrm{~b}$ & $26.0 \mathrm{a}$ & 0.005 \\
\hline Circling & 0 & 0 & 0 & 2.30 & 0.397 \\
\hline Manipulation of environment & 0 & 0 & 0 & 0.54 & 0.397 \\
\hline \multicolumn{6}{|l|}{ Rest behavior } \\
\hline Prone, head up & $111.75 \mathrm{a}$ & $141.21 \mathrm{a}$ & $162.42 \mathrm{a}$ & $78.29 \mathrm{~b}$ & 0.050 \\
\hline Sit & $54.00 \mathrm{a}$ & $44.08 \mathrm{ab}$ & $48.42 \mathrm{a}$ & $34.37 \mathrm{~b}$ & 0.036 \\
\hline Sit, head in the grid & $49.29 \mathrm{a}$ & $8.75 \mathrm{~b}$ & $19.67 \mathrm{~b}$ & $9.41 \mathrm{~b}$ & 0.025 \\
\hline Stand & $26.67 \mathrm{~b}$ & $76.33 \mathrm{a}$ & $19.42 b$ & $60.79 a$ & 0.004 \\
\hline Oral behaviors & 4.67 & 1.67 & 3.42 & 2.54 & 0.515 \\
\hline Prone, head down & 25.00 & 0 & 22.00 & 37.50 & 0.376 \\
\hline Stand on two legs & 5.87 & 0 & 6.83 & 0.33 & 0.415 \\
\hline \multicolumn{6}{|l|}{ Movement behaviors } \\
\hline Walk & $8.29 \mathrm{~b}$ & $25.04 \mathrm{a}$ & $11.62 b$ & $30.21 \mathrm{a}$ & 0.021 \\
\hline Sniff & 0.62 & 0 & 1.54 & 0.21 & 0.679 \\
\hline Urinating & 0 & 0 & 0 & 0 & 0 \\
\hline Defecating & 0 & 3.62 & 0 & 2.29 & 0.548 \\
\hline Drinking & 4.75 & 4.83 & 1.29 & 6.46 & 0.331 \\
\hline Oral behaviors & 2.87 & 3.33 & 1.71 & 2.62 & 0.956 \\
\hline Eating & 2.25 & 0 & 0 & 7.79 & 0.412 \\
\hline
\end{tabular}

$a, b$ different lowercase letters in the rows (inside category) indicate significant difference $(p<0.05)$. A total time of 300 seconds of observation for each breed.

Prone, head up, the most observed behavior $(P<0.05)$, did not vary among the breeds $(P>0.05)$. Sit and sit and head in the grid were the most observed behaviors in German Shepherd $(P<0.05)$ dogs, the stand was the most observed behavior in Belgian Shepherd Malinois and Rottweiler dogs. German Shepherd dogs showed greater oral behaviors $(P<0.05)$ than other dogs. Standing on two legs was the most observed behavior in German Shepherd and Doberman dogs (Table 2).

Regarding movement behaviors, the most observed behavior was walk in Rottweiler dogs and Belgian Shepherd Malinois dogs compared to that in other dogs, while sniffing, defecating, drinking, oral behaviors, and eating did not show significant differences among the breeds $(P>0.05)$. Urinating was not observed during the entire period.

Stereotypic behaviors were higher in Rottweiler dogs $(P<0.05)$ than German Shepherd, Belgian Malinois Shepherd, and Doberman dogs.Doberman dogs did not show stereotypic behaviors (Table 2).

Comparing the WS and CS during the periods (morning and afternoon), stereotypic behaviors were high in the morning on both shifts $(P<0.05)$, and they were not observed in 
the afternoon. The resting behavior was longer in the afternoon in both shifts, without significant differences, while it was significantly higher in the morning in the CS than in the WS $(P<0.05$; Table 3).

Table 3. Mean values of behavior of military working dogs of different breeds during the working and control shifts in the morning and afternoon expressed as seconds per activity.

\begin{tabular}{|c|c|c|c|c|c|}
\hline \multirow{2}{*}{ Behavior } & \multicolumn{2}{|c|}{ Working shifts (WS) } & \multicolumn{2}{|c|}{ Control shifts (CS) } & \multirow{2}{*}{ P value } \\
\hline & Morning & Afternoon & Morning & Afternoon & \\
\hline \multicolumn{6}{|l|}{ Stereotypic behaviors } \\
\hline Repetitive walking & $25.2 \mathrm{a}$ & $0 \mathrm{~b}$ & $7.2 \mathrm{~b}$ & $0 \mathrm{~b}$ & 0.0186 \\
\hline Circling & 0 & 0 & 2.33 & 0 & 0.320 \\
\hline Manipulation of environment & 0 & 0 & 0.54 & 0 & 0.320 \\
\hline \multicolumn{6}{|l|}{ Rest behaviors } \\
\hline Prone, head up & $49.37 c$ & $165.42 \mathrm{a}$ & $110.75 \mathrm{~b}$ & $168.13 \mathrm{a}$ & 0.018 \\
\hline Sit & $72.84 \mathrm{a}$ & $44.91 \mathrm{~b}$ & $22.04 \mathrm{~b}$ & $41.08 \mathrm{~b}$ & 0.001 \\
\hline Sit, head in the grid & $28 \mathrm{~b}$ & $10.5 \mathrm{c}$ & $44 \mathrm{a}$ & $4.62 \mathrm{c}$ & 0.067 \\
\hline Stand & $77.08 \mathrm{a}$ & $23.87 \mathrm{c}$ & $54.29 \mathrm{~b}$ & $27.97 \mathrm{C}$ & 0.195 \\
\hline Oral behaviors & $5.2 \mathrm{a}$ & $0 \mathrm{c}$ & $5 a$ & $2.08 \mathrm{~b}$ & 0.701 \\
\hline Prone, head down & $5.17 \mathrm{~b}$ & $25 a$ & $25 \mathrm{a}$ & $29.34 \mathrm{a}$ & 0.612 \\
\hline Stand on two legs & $7.17 \mathrm{a}$ & $\mathrm{Ob}$ & $5.87 \mathrm{~b}$ & $0 \mathrm{~b}$ & 0.309 \\
\hline \multicolumn{6}{|l|}{ Movement behaviors } \\
\hline Walk & 22.34 & 12.7 & 25.75 & 14.37 & 0.079 \\
\hline Sniff & 0 & 0 & 0 & 2.37 & 0.103 \\
\hline Urinating & 0 & 0 & 0 & 0 & 0 \\
\hline Defecating & 0 & 5.91 & 0 & 0 & 0.160 \\
\hline Drinking & 1.41 & 9.17 & 1.37 & 5.37 & 0.177 \\
\hline Oral behaviors & 6.5 & 2.25 & 0 & 1.79 & 0.070 \\
\hline Eating & 0 & 0 & 0 & 10.04 & 0.309 \\
\hline
\end{tabular}

$a, b$ different lowercase letters indicate significant difference in the rows $(p<0.05)$. A total time of 300 seconds of observation for each period (morning/afternoon).

\section{Cortisol levels}

The salivary cortisol level in the WS was $0.504 \mu \mathrm{g} / \mathrm{dL}$ and did not differ from that in the CS $(0.400 \mu \mathrm{g} / \mathrm{dL}$; Figure $1 \mathrm{~A})$. However, differences between periods were observed; the higher average level was detected at 6 p.m. than at 7 a.m. $(0.592 \mu \mathrm{g} / \mathrm{dL}$ vs. $0.312 \mu \mathrm{g} / \mathrm{dL} ; P=0.0234$; Figure 1B). No interactions between the shifts and periods were observed $(P>0.05)$.

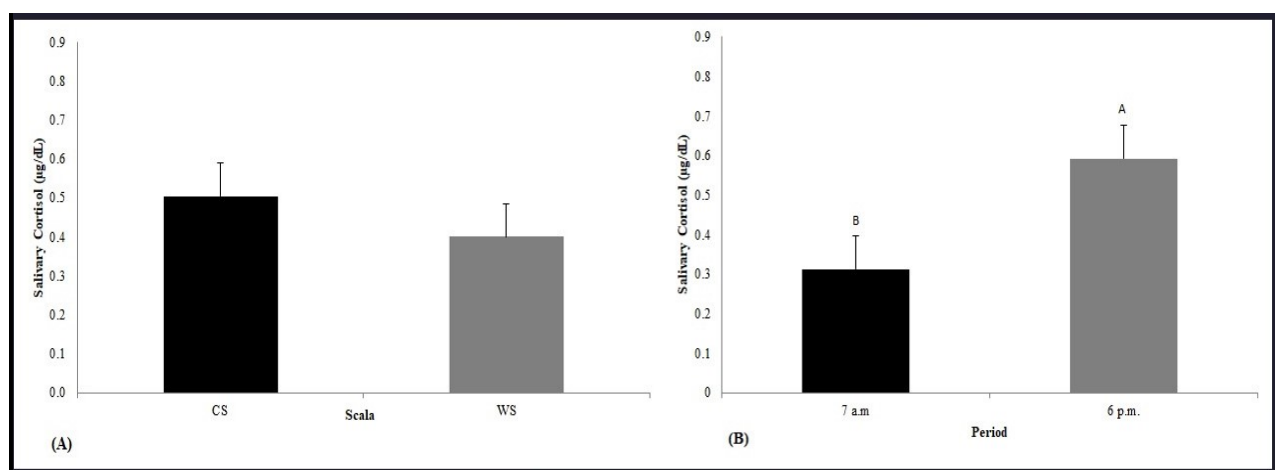

Figure 1. Mean values ( \pm standard error) of salivary cortisol measured working and control shifts $(A)$ and Salivary Cortisol measured at 7 a.m and 6 p.m in the working and control shifts (B). Different capital letters $(A, B)$ indicate significant difference within the periods or time $(p<0.05)$.

Rottweiler $(0.614 \mu \mathrm{g} / \mathrm{dL})$ and German Shepherd $(0.567 \mu \mathrm{g} / \mathrm{dL})$ dogs had higher salivary cortisol levels $(P>0.05)$ than other dogs (Figure 2$)$ at 7 a.m. and 6 p.m. In the WS, German Shepherd and Rottweiler dogs had higher $(P<0.05)$ salivary cortisol levels than Doberman and Belgian Shepherd Malinois dogs (Figure 3). 


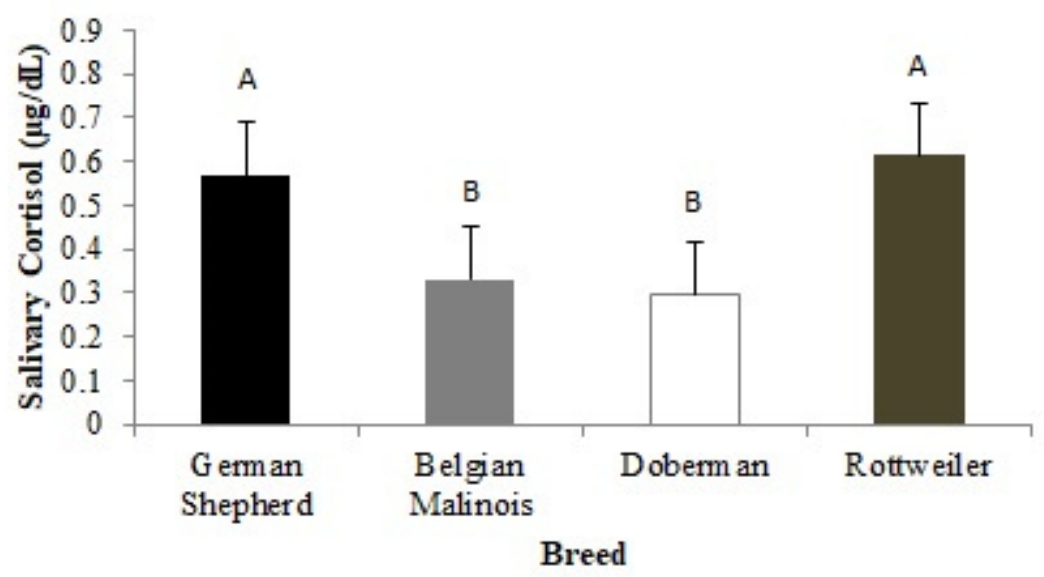

Figure 2. Mean values ( \pm standard error) of salivary cortisol of German Shepherd, Belgian Shepherd Malinois, Doberman and Rottweiler measured at 07 a.m and 6 p.m. A, B different capital lowercase letters indicate significant difference in the rows $(p<0.05)$.

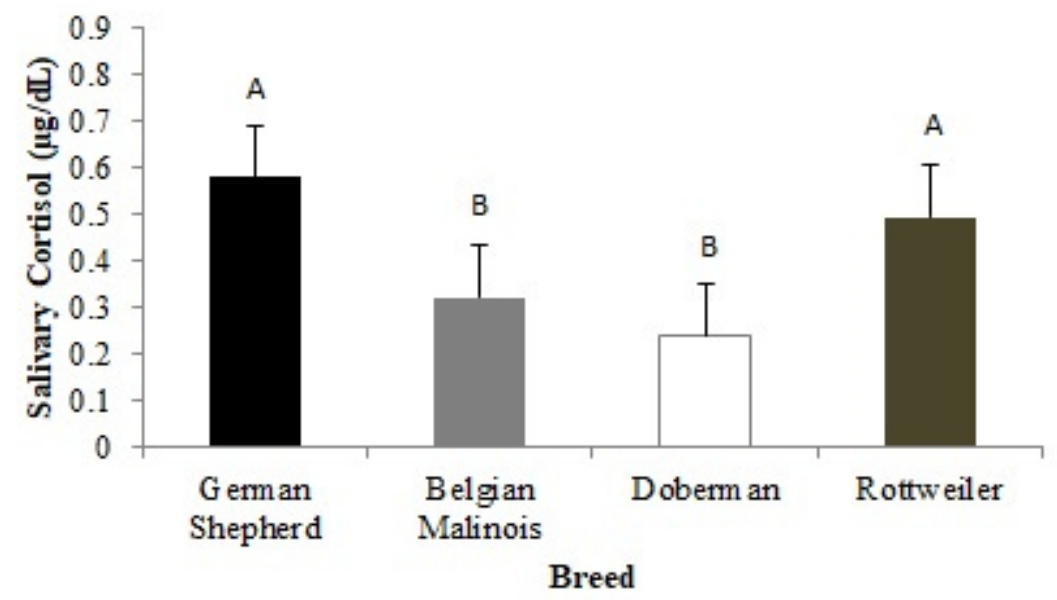

Figure 3. Mean values ( \pm standard error) of salivary cortisol during the working shifts at different breeds. $A, B$ different capital lowercase letters indicate significant difference in the rows $(p<0.05)$.

When considering the different periods in the WS, there were no differences in the levels $(P>0.05)$ among the samples at 07:00 a.m. (0.264 $\mu \mathrm{g} / \mathrm{dL}), 10: 00$ a.m. $(0.324 \mu \mathrm{g} / \mathrm{dL})$, and 1:00 p.m. (0.312 $\mu \mathrm{g} / \mathrm{dL})$; however, the levels were higher $(P<0.05)$ at 6:00 p.m. $(0.745 \mu \mathrm{g} / \mathrm{dL}$; Figure 4$)$.

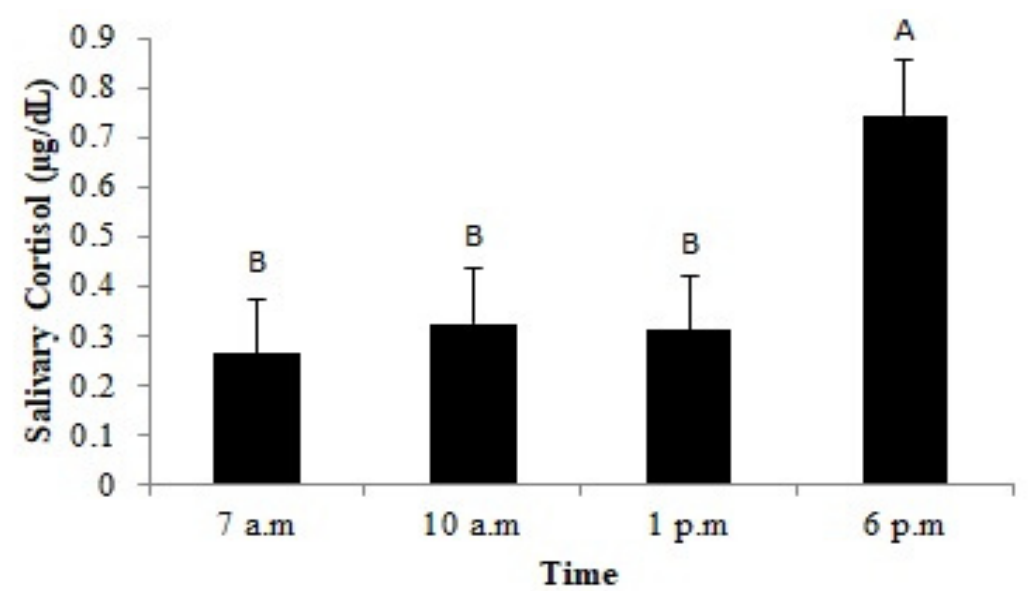

Figure 4. Mean values ( \pm standard error) of salivary cortisol of military dogs during working shifts. $A, B$ different capital lowercase letters indicate significant difference in the rows $(p<0.05)$. 


\section{Semen quality}

All testicles were in firm condition as desired. Semen analysis was according to the pattern for dogs and was based on a total of eight samples (Supplementary Material 1). German Shepherd, Belgian Malinois Shepherd, and Doberman dogs had PM values between $80 \%$ to $90 \%$, while Rottweiler dogs had PM values of $60 \%$ (Table 4). German Shepherd, Belgian Malinois Shepherd, and Doberman dogs had VIG values between 3 and 4 (good), while Rottweiler dogs had VIG values of 2 (very slow).

Table 4. Values of spermatic concentration (CONC), sperm vigor (VIG), progressive sperm motility (PMot), minor defects (MiD), major defects (MaD), and total defects (TD) of military working dogs.

\begin{tabular}{|c|c|c|c|c|c|c|}
\hline Breed & $\frac{\text { CONC }}{\left(\times 10^{3} \text { sperm } / \mathrm{mL}\right)}$ & $\begin{array}{l}\text { VIG } \\
(0-5)\end{array}$ & $\begin{array}{c}\text { PMot } \\
\text { (\%) }\end{array}$ & $\begin{array}{r}\text { MiD } \\
\text { (\%) }\end{array}$ & $\begin{array}{c}\text { MaD } \\
(\%)\end{array}$ & $\begin{array}{l}\text { TD } \\
(\%)\end{array}$ \\
\hline German Shepherd & 128.356 & 3 & 80 & 2.5 & 10.5 & 13.0 \\
\hline German Shepherd & 110.544 & 3 & 80 & 3.0 & 5.5 & 8.5 \\
\hline Belgian Malinois & 136.128 & 4 & 90 & 2.0 & 6.5 & 8.5 \\
\hline Belgian Malinois & 129.124 & 4 & 90 & 2.5 & 7.5 & 10.0 \\
\hline Doberman & 126.020 & 3 & 80 & 4.0 & 8.0 & 12.0 \\
\hline Doberman & 131.226 & 3 & 80 & 3.0 & 5.0 & 8.0 \\
\hline Rottweiler & 18.992 & 2 & 60 & 4.0 & 26.5 & 30.5 \\
\hline Rottweiler & 20.826 & 2 & 60 & 3.0 & 25.0 & 28.0 \\
\hline
\end{tabular}

The sperm concentration varied between 100,000 and $136,000 \times 10^{3}$ sperm per $\mathrm{mL}$ for German Shepherd, Belgian Malinois Shepherd, and Doberman dogs and between 18,000 and $20,000 \times 10^{6}$ sperm per $\mathrm{mL}$ for Rottweiler dogs. Minor and major defects, considering different pathologies, were found in all breeds, and a higher number of defects were found in Rottweiler dogs (total defects $+-29,25 \%$ ) than in other dogs.

\section{Discussion}

Behavior characteristics are related to different physiological and neuroendocrine responses under stress (Etim et al., 2013). Similar to our study, when the military dogs finished their work day they exhibited stereotypic behaviors such as repetitive walking behavior and Oral behaviors, which can be a sign of restlessness (Foyer et al., 2016). This restlessness can be attributed to previously defined situations as stimuli that could be anticipated (e.g. training method) or the presence of a human (Beerda et al., 1998). Increased Oral behaviors may be associated with training, as dogs showed more this behavior when training together (Clark et al., 1997).

During the resting period, prone, head up was the most frequent behavior for all breeds; however, there was no apathy or periods of inactivity, which is in contrast to that observed in challenged dogs (Beerda et al., 1997; Haverbeke et al., 2008), shelter dogs (Hubrecht et al., 1992), and laboratory dog models (Hetts et al., 1992), which were under similar conditions. The dogs were relaxed when sitting down or laying down with no tension in muscles (Lindsay, 2005), similar to our study.

No animal showed stereotypic behaviors like to had excessive corporal manipulation (scratching, licking, and biting), coprophagy, excessive vocalization, leg lifting; repeated sniffing and urination, and stereotypic behaviors (Hubrecht et al., 1992; Hetts et al., 1992; Beerda et al., 1997; Haverbeke al., 2008).

The similarities in the animal's growth and their given goals since their puppy phase in the same kennel system (Hennessy et al., 1998; Stephen and Ledger, 2005) can explain the lower variation in all behaviors assessed between breeds. Rottweiler dogs had different behaviors from other dogs, which can be explained by the individual perception of the environment. The individuality among the breeds can be related to the temperament and motivation to associate specific activities (Schilder, 1992; Coppinger and Schneider, 1995). Furthermore, since Rottweiler dogs show energetic behavior, it is essential that these dogs have enough space for 
constant physical exercises; otherwise, they may experience stress and their behavior may be affected mainly by limited physical activity or due to the insufficient amount of training to dispense energy (Beauchamp, 2000; AKC, 2020).

The basal salivary cortisol level in dogs ranges from 0.02 to $0.3 \mu \mathrm{g} / \mathrm{dL}$ (Bennett and Hayssen, 2010; Wenger-Riggenbach et al., 2010). In this study, the average salivary cortisol level in the CS was between 0.361 and $0.438 \mu \mathrm{g} / \mathrm{dL}$ and that in the WS was between 0.312 and $0.592 \mu \mathrm{g} / \mathrm{dL}$. This result implies that even under resting conditions (CS), working dogs have high cortisol levels, which means they can be stressed for a long period of time (Hekman et al., 2012).

The cortisol level during the WS did not show significant alterations, probably because the animals were under the same stimuli, showing that they are able to deal with the same challenges since their training routine and the environment were the same for all the breeds, with small or no variations in cortisol levels (Haverbeke al., 2008). An increase in cortisol levels occurred when the dogs returned from work due to external activities. They encounter constant challenges because they are exposed to various uncommon situations such as traffic jams, distraction such as noises, and unknown people and animals (Svobodova et al., 2014). Circadian rhythm of cortisol increases at night and decreases during the day, which is similar in clinically normal dogs (Camacho, 1987). Also, normalization of the cortisol levels always occurred within 60 min following the administration of one unique stimulus (unpredictable shock) in dogs (Beerda et al., 1998), and the peak of cortisol levels can occur between 60 to 120 minutes after a punctual stress (Henrique et al., 2017).

Behavior characteristics are related to different physiological and neuroendocrine responses under stress and are consistent. Some studies have found only physiological or behavioral differences (Beerda et al., 1997), similar to our study, when the dogs finished their work day. Occasionally, when the cortisol level is higher and there are no behavioral activities related to stress, cortisol levels may be correlated to physical work (Sundman et al., 2019). This was observed for German Shepherd dogs, which showed high cortisol levels, but their behavior was not affected (Foyer et al., 2016). However, Rottweiler dogs had higher salivary cortisol levels than other dogs, possibly because these dogs exhibited greater stereotypic behaviors such as repetitive walking behavior and movement behavior (walk), which can be a sign of restlessness.

Our findings show that it is possible that Rottweiler dogs are more susceptible to stress as they present a different response than other dogs subjected to the same stimuli during training, rest, or military work. Dogs have different coping strategies responses to the same stimulus (Chmelíková et al., 2020) due to several reasons such as breed, temperament, personality, and previous individual experiences (Marliani et al., 2018). The breed has a great effect on the personality of the animal and, consequently, on the suitability of the dog to the military working (Netto and Planta, 1997).

The breed factor is also important in the analysis of dog semen, since total sperm in the ejaculate is based on testicular size and there is also a shortage of specific information of the breed (Kustritz, 2007). In semen analysis, the German Shepherd, Belgian Malinois Shepherd and Doberman, and dogs showed satisfactory results for all the reproductive parameters. The Rottweiler dogs semen analysis showed lower sperm count, PM, VIG, MiDs, MaDs, and TDs. As previously described in the Rottweiler breed, negative changes in behavior can be related to stress. The response to stress activates the hypothalamic-pituitary-adrenal axis and releases cortisol that possibly affected semen quality (Curley et al., 2008). High glucocorticoid levels decrease the production and secretion of testosterone from the Leydig cells and spermatogenesis (Brownlee et al., 2005), a process of division and differentiation of germ cells into spermatozoa (Johnson et al., 2000). Any change in this process has a negative effect on the semen quality such as sperm count, percentage of motile sperm, and percentage of morphologically normal sperm, which is observed in the Rottweiler breed (Janevic et al., 2014; Faeza et al., 2019). The low percentage of normal sperm morphology exhibited by the Rottweiler breed is possibly due to the malfunction of the epididymis because of the influence of stressors (Almeida et al., 1998). Stress factors also significantly increase MaDs, which can be associated with low fertility semen, but these abnormalities cannot be related to infertility (Vannucchi et al., 1998; Kumar and Singh, 2015). Infertility may be due to a combination of low 
spermatic concentration, poor sperm motility, or abnormal sperm morphology (Kumar and Singh, 2015).

Despite having higher TDs, the fertility of the Rottweiler dog is not affected as $>69.5 \%$ sperm are normal and fertility can be affected when $<60 \%$ of the sperm are abnormal (Oettlé, 1993). In addition, other factors must be considered regarding the low performance of the Rottweiler dogs as the breed factor is important in the analysis of the semen from dogs, the total sperm count in the ejaculate is based on testicular size and there is also a shortage of specific information of the breed (Kustritz, 2007).

The semen parameters are positively correlated with each other, the PM is positively correlated with spermatic concentration (Agarwal et al., 2003) and the higher percentage of abnormal sperm is positively correlated with PM in dogs (Ellington et al., 1993); therefore, the number of sperm pathologies found in the Rottweiler breed may have contributed to the lower PM values than that indicated for the species, which is around 70\% (Freshman, 2002), and VIG below three (CBRA, 2013). These findings are similar to those described in Rottweiler working dogs, which also had the same modification patterns, except for spermatic concentration and minor defects (Baptista et al., 2009).

\section{Conclusion}

In this study we conclude that military dogs presented more stressful signs when they are in working period as stereotypic behavior, but cortisol levels and semen quality was not affected, only when breeds were analyzed separately. However, as we have a small sample size of each breed, results must be analyzed carefully.

\section{Acknowledgements}

We acknowledge $1^{\text {st }}$ Especial Action Police Crowd (in Portuguese BAEP), Campinas, SP, Brazil for animal support. This study was financed in part by the Coordenação de Aperfeiçoamento de Pessoal de Nível Superior - Brasil (CAPES) - Finance Code 001.

\section{References}

Agarwal A, Sharma RK, Nelson DR. New semen quality scores developed by principal component analysis of semen characteristics. J Androl. 2003;24(3):343-52. http://dx.doi.org/10.1002/j.19394640.2003.tb02681.x. PMid:12721209.

AKC - American Kennel Club [homepage on the Internet]. Rottweiler; 2020 [cited 2020 Aug 4]. Available from: https://www.akc.org/dog-breeds/rottweiler.

Almeida SA, Petenusci SO, Anselmo-franci JA, Rosa-e-Silva AAM, Lamano-Carvalho TL. Decreased spermatogenic and androgenic testicular functions in adult rats submitted to immobilization-induced stress from prepuberty. Braz J Med Biol Res. 1998;31(11):1443-8. http://dx.doi.org/10.1590/S0100879X1998001100013. PMid:9921282.

Ax RL, Dally M, Didion AB, Lenz RW, Love CC, Varner DD, Hafez B, Ellin ME. Avaliação do sêmen. In: Hafez ESE, Hafez B, editors. Reprodução animal. São Paulo: Manole; 2004. p. 372-373.

Baptista CA So, Hatamotozervoudakis LK, Barnabe VH, Nichi M, Oliveira CA. Efeitos do estresse de trabalho sobre parâmetros seminais de cães da raça Rottweiler. Braz J Med Biol Res. 2009;46:280-7.

Beauchamp RG. Rottweilers for dummies. Indiana: Wiley Publishing; 2000. p. 467.

Beerda B, Schilder MBH, van Hooff JARAM, De Vries HW, Mol JA. Behavioural, saliva cortisol and heart rate responses to different types of stimuli in dogs. Appl Anim Behav Sci. 1998;58(3-4):365-81. http://dx.doi.org/10.1016/S0168-1591(97)00145-7.

Beerda B, Schilder MBH, van Hooff JARAM, Vries HW. Manifestations of chronic and acute stress in dogs. Appl Anim Behav Sci. 1997;52(3-4):307-19. http://dx.doi.org/10.1016/S0168-1591(96)01131-8.

Bennett $A$, Hayssen V. Measuring cortisol in hair and saliva from dogs: coat color and pigment differences. Domest Anim Endocrinol. 2010;39(3):171-80.

http://dx.doi.org/10.1016/j.domaniend.2010.04.003. PMid:20705413. 
Broom DM, Fraser AF. Comportamento e bem-estar de animais domésticos. 4th ed. Barueri: Manole; 2010. p.421.

Brownlee KK, Moore AW, Hackney AC. Relationship between circulating cortisol and testosterone: influence of physical exercise. J Sports Sci Med. 2005;4(1):76-83. PMid:24431964.

Burghardt WF Jr. Behavioral considerations in the management of working dogs. Vet Clin North Am Small Anim Pract. 2003;33(2):417-46, viii. http://dx.doi.org/10.1016/S0195-5616(02)00133-X. PMid:12701519.

Camacho AA. Determinação dos níveis séricos de cortisol pelo método de radioimunoensaio em cães clinicamente normais [dissertation]. Minas Gerais: Universidade Federal de Minas Gerais; 1987. Portuguese.

CBRA - Colégio Brasileiro de Reprodução Animal. Manual para exame andrológico e avaliação de sêmen animal. 3rd ed. Belo Horizonte: CBRA; 2013. p.49

Chmelíková E, Bolechová P, Chaloupková H, Svobodová I, Jovičić M, Sedmíková M. Salivary cortisol as a marker of acute stress in dogs: a review. Domest Anim Endocrinol. 2020;72:106428. http://dx.doi.org/10.1016/j.domaniend.2019.106428. PMid:32213439.

Clark JD, Rager DR, Crowell-Davis S, Evans DL. Housing and exercise of dogs: effects on behavior, immune function, and cortisol concentration. Lab Anim Sci. 1997;47(5):500-10. PMid:9355093.

Coppinger R, Schneider R. Evolution of working dogs. In: Serpell J, editor. The domestic dog: its evolution, behaviour and interactions with people. Cambridge: University Press; 1995. p. 21-47.

Curley KO Jr, Neuendorff DA, Lewis AW, Cleere JJ, Welsh TH Jr, Randel RD. Functional characteristics of the bovine hypothalamic-pituitary-adrenal axis vary with temperament. Horm Behav. 2008;53(1):207. http://dx.doi.org/10.1016/j.yhbeh.2007.08.005. PMid:17916358.

Ellington J, Scarlett J, Meyers-Wallen V, Mohammed HO, Surman V. Computer assisted sperm analysis of canine spermatozoa motility measurements. Theriogenology. 1993;40(4):725-33. http://dx.doi.org/10.1016/0093-691X(93)90208-M. PMid:16727354.

Etim NN, Williams ME, Evans El, Offiong EEA. Physiological and behavioural responses of farm animals to stress: implications to animal productivity. AJAAR. 2013;1:53-61.

Faeza NMN, Jesse FFA, Hambali IU, Odhah MN, Umer M, Wessam MMS, Mohd-Azmi ML, Wahid AH. Responses of testosterone hormone concentration, semen quality, and its related pro-inflammatory cytokines in bucks following Corynebacterium pseudotuberculosis and its mycolic acid infection. Trop Anim Health Prod. 2019;51(7):1855-66. http://dx.doi.org/10.1007/s11250-019-01878-2. PMid:30945156.

Foyer P, Svedberg AM, Nilsson E, Wilsson E, Faresjö $\AA$, Jensen P. Behavior and cortisol responses of dogs evaluated in a standardized temperament test for military working dogs. J Vet Behav. 2016;11:7-12. http://dx.doi.org/10.1016/j.jveb.2015.09.006.

Freshman JL. Semen collection and evaluation. Clin Tech Small Anim Pract. 2002;17(3):104-7. http://dx.doi.org/10.1053/svms.2002.34326. PMid:12476812.

Hall NJ, Protopopova A, Wynne CDL. The role of environmental and owner-provided consequences in canine stereotypy and compulsive behavior. J Vet Behav. 2015;10(1):24-35. http://dx.doi.org/10.1016/j.jveb.2014.10.005.

Haverbeke A, Diederich C, Depiereux E, Giffroy JM. Cortisol and behavioral responses of working dogs to environmental challenges. Physiol Behav. 2008;93(1-2):59-67. http://dx.doi.org/10.1016/j.physbeh.2007.07.014. PMid:17868751.

Hekman JP, Karas AZ, Dreschel NA. Salivary cortisol concentrations and behavior in a population of healthy dogs hospitalized for elective procedures. Appl Anim Behav Sci. 2012;141(3-4):149-57. http://dx.doi.org/10.1016/j.applanim.2012.08.007. PMid:24204086.

Hekman JP, Karas AZ, Sharp CR. Psychogenic stress in hospitalized dogs: cross species comparisons, implications for health care, and the challenges of evaluation. Anim. 2014;4(2):331-47. http://dx.doi.org/10.3390/ani4020331. PMid:25126422.

Hennessy MB, Williams MT, Miller DD, Douglas CW, Voith VL. Influence of male and female petters on plasma cortisol and behavior: can human interaction reduce the stress of dogs in a public animal shelter? Appl Anim Behav Sci. 1998;61(1):63-77. http://dx.doi.org/10.1016/S0168-1591(98)00179-8.

Henrique FL, Titto EAL, Zanella AJ, Hooper HB, Pulido-Rodriguez LF, Longo ALS, da Cunha Leme-dosSantos TM, Pereira AMF, Titto CG. Simulated disease process during late pregnancy compromises developmental outcomes of lambs independently of the weaning method applied. Small Rumin Res. 2017;155:39-44. http://dx.doi.org/10.1016/j.smallrumres.2017.09.004. 
Hetts S, Clark JD, Calpin JP, Arnold CE, Mateo JM. Influence of housing conditions on beagle behaviour. Appl Anim Behav Sci. 1992;34(1-2):137-55. http://dx.doi.org/10.1016/S0168-1591(05)80063-2.

Hubrecht RC, Serpell JA, Poole TB. Correlates of pen size and housing conditions on the behavior of kenneled dogs. Appl Anim Behav Sci. 1992;34(4):365-83. http://dx.doi.org/10.1016/S01681591(05)80096-6.

Janevic T, Kahn LG, Landsbergis P, Cirillo PM, Cohn BA, Liu X, Factor-Litvak P. Effects of work and life stress on semen quality. Fertil Steril. 2014;102(2):530-8. http://dx.doi.org/10.1016/j.fertnstert.2014.04.021. PMid:24856463.

Johnson L, Ing NH, Welsh TH, Varner DD, Scrutchfield WL, Martin MT. Efficiency of spermatogenesis in animals and humans. J Anim Sci. 2000;77(E-Suppl):1-47. http://dx.doi.org/10.2527/jas2000.77ESuppl1t.

Kolster KA. Evaluation of canine sperm and management of semen disorders. In: Christensen BW, editor. Veterinary clinics of North America: small animal practice. Philadelphia: Elsevier; 2018. p. 533-545. http://dx.doi.org/10.1016/j.cvsm.2018.02.003.

Kumar JA, Balaji T, Priyadarshini CS, Subramanian M, Sundaramurthi I. Non concurrent multimodal stress decreases sperm quality and motor activity in male wistar albino rats. Biomed Pharmacol J. 2019;12(3):1505-17. http://dx.doi.org/10.13005/bpj/1781.

Kumar N, Singh AK. Trends of male factor infertility, an important cause of infertility: a review of literature. J Hum Reprod Sci. 2015;8(4):191-6. http://dx.doi.org/10.4103/0974-1208.170370. PMid:26752853.

Kustritz MVR. The value of canine semen evaluation for practitioners. Theriogenology. 2007;68(3):329-37. http://dx.doi.org/10.1016/j.theriogenology.2007.04.017. PMid:17481723.

Kutzler MA. Semen collection in the dog. Theriogenology. 2005;64(3):747-54. http://dx.doi.org/10.1016/j.theriogenology.2005.05.023. PMid:15993482.

Lazarowski L, Waggoner LP, Krichbaum S, Singletary M, Haney P, Rogers B, Angle C. Selecting dogs for explosives detection: behavioral characteristics. Front Vet Sci. 2020;7:597. http://dx.doi.org/10.3389/fvets.2020.00597. PMid:33088829.

Lindsay SR. Handbook of applied dog behavior and training: procedures and protocols. Ames: Blackwell; 2005. Vol. 3, p. 751-59. . http://dx.doi.org/10.1002/9780470344514.app3.

Marliani G, Accorsi PA, Mondo E, Mucciante L. The importance of welfare and temperament on the performance of police dog. Dog Behav. 2018;3:13-8.

Mills D, Karagiannis C, Zulch $\mathrm{H}$. Stress-its effects on health and behavior: a guide for practitioners. Vet Clin North Am Small Anim Pract. 2014;44(3):525-41. http://dx.doi.org/10.1016/j.cvsm.2014.01.005. PMid:24766698.

Möstl E, Palme R. Hormones as indicators of stress. Domest Anim Endocrinol. 2002;23(1-2):67-74. http://dx.doi.org/10.1016/S0739-7240(02)00146-7. PMid:12142227.

Netto WJ, Planta DJU. Behavioural testing for aggression in the domestic dog. Appl Anim Behav Sci. 1997;52(3-4):243-63. http://dx.doi.org/10.1016/S0168-1591(96)01126-4.

Oettlé EE. Sperm morphology and fertility in the dog. J Reprod Fertil Suppl. 1993;47:257-60. PMid:8229933.

Papa FO, Bicudo SD, Alvarenga MA, Ramires PRN, Carvalho IM, Lopes MD. Coloração espermática segundo Karras modificado pelo emprego do Barbatimão (Sthyphnodendrum barbatiman). Arq Bras Med Vet Zootec. 1988;40:115-23.

Petersson M, Uvnäs-Moberg K, Nilsson A, Gustafson L, Hydbring-Sandberg E, Handlin L. Oxytocin and cortisol levels in dog owners and their dogs are associated with behavioral patterns: an exploratory study. Front Psychol. 2017;8:1796-804. http://dx.doi.org/10.3389/fpsyg.2017.01796. PMid:29081760.

Rooney NJ, Clark CC, Casey RA. Minimizing fear and anxiety in working dogs: a review. J Vet Behav: Clin Appl Res. 2016;16:53-64. http://dx.doi.org/10.1016/j.jveb.2016.11.001.

São Paulo. Decreto n 40.400, de 24 de outubro de 1995. Aprova Norma Técnica Especial relativa à instalação de estabelecimentos veterinários. Diário Oficial do Estado de São Paulo; São Paulo; 24 outubro 1995.

Schilder MB. Stress and welfare and its parameters in dogs. Tijdschr Diergeneeskd. 1992;117(Suppl 1):53-4. PMid:1585336. 
Starling JMC, Silva RG, Negrão JA, Maia ASC, Bueno AR. Variação estacional dos hormônios tireoideanos e do cortisol em ovinos em ambiente Tropical. Rev Bras Zootec. 2005;34(6):2064-73. http://dx.doi.org/10.1590/S1516-35982005000600032.

Stephen JM, Ledger RA. An audit of behavioral indicators of poor welfare in kenneled dogs in the United Kingdom. J Appl Anim Welf Sci. 2005;8(2):79-96. http://dx.doi.org/10.1207/s15327604jaws0802_1. PMid:16277592.

Sundman A, Van Poucke EV, Holm AS, Faresjö A, Theodorsson E, Jensen P, Roth LSV. Long-term stress levels are synchronized in dogs and their owners. Sci Rep. 2019;9(1):7391. http://dx.doi.org/10.1038/s41598-019-43851-x. PMid:31171798.

Svobodova I, Chaloupkova H, Koncel R, Bartos L, Hradecká L, Jebavý L. Cortisol and secretory immunoglobulin a response to stress in German Shepherd dogs. PLoS One. 2014;9(3):e90820. http://dx.doi.org/10.1371/journal.pone.0090820. PMid:24637917.

Vannucchi Cl, Satzinger S, Santos SEC. Avaliação seminal em cães- aspectos práticos. Clín Vet. 1998;3:227.

Wenger-Riggenbach B, Boretti FS, Quante S, Schellenberg S, Reusch CE, Sieber-RuckstuhI NS. Salivary cortisol concentrations in healthy dogs and dogs with hypercortisolism. J Vet Intern Med. 2010;24(3):551-6. http://dx.doi.org/10.1111/j.1939-1676.2010.0494.x. PMid:20384959.

\section{Author contributions}

GBA: conceptualization, investigation, methodology, validation; MHAP: validation, writing - original draft, writing - review and editing; CGT: conceptualization, supervision writing - review and editing; DSM: conceptualization, project administration, supervision, writing - review and editing. 
Stress in male military working dogs

\section{Supplementary Material}

Supplementary material accompanies this paper.

Supplementary Material 1 - Semen characteristics

This material is available as part of the online article from https://www.scielo.br/j/ar 